\title{
Effects of precalving body condition and prepartum feeding level on gene expression in circulating neutrophils
}

\author{
M. A. Crookenden, ${ }^{*} \dagger^{1}$ C. G. Walker, ${ }^{* 2}$ A. Heiser, $† \ddagger$ A. Murray, $\dagger$ V. S. R. Dukkipati, $\dagger$ J. K. Kay,§ S. Meier,§ \\ K. M. Moyes,\# M. D. Mitchell,II J. J. Loor,I and J. R. Roche§ \\ *DairyNZ, c/o University of Auckland, 3A Symonds Street, Auckland 1010, New Zealand \\ †Institute of Vet, Animal and Biomedical Sciences, Massey University, Palmerston North 4442, New Zealand \\ †AgResearch, Hopkirk Research Institute, Palmerston North 4442, New Zealand \\ $\S$ DairyNZ, Cnr Ruakura and Morrinsville Rds (SH26), Newstead, Hamilton 3284, New Zealand \\ \#Department of Animal and Avian Sciences, University of Maryland, College Park 20742 \\ IIUniversity of Queensland, Centre for Clinical Research, Herston, Queensland 4029, Australia \\ IDepartment of Animal Sciences, University of Illinois, Urbana 61801
}

\section{ABSTRACT}

Extensive metabolic, physiological, and immunological changes are associated with calving and the onset of lactation. As a result, cows transitioning between pregnancy and lactation are at a greater risk of metabolic and infectious diseases. The ability of neutrophils to mount an effective immune response to an infection is critical for its resolution, and increasing evidence indicates that precalving nutrition affects postpartum neutrophil function. The objectives of the current study were to investigate the effect of 2 precalving body condition scores (BCS; 4 vs. 5 on a 10-point scale) and 2 levels of feeding ( 75 vs. $125 \%$ of estimated maintenance requirements) on gene expression in circulating neutrophils. We isolated RNA from the neutrophils of cows $(\mathrm{n}=45)$ at 5 time points over the transition period: precalving $(-1 \mathrm{wk})$, day of calving (d 0$)$, and postcalving at wk 1,2, and 4. Quantitative reverse transcriptase PCR with custom-designed primer pairs and Roche Universal Probe Library (Roche, Basel, Switzerland) chemistry, combined with microfluidics integrated fluidic circuit chips (96.96 dynamic array), were used to quantify the expression of 78 genes involved in neutrophil function and 18 endogenous control genes. Statistical significance between time points was determined using repeated measures ANOVA with Tukey-Kramer multiple-testing correction to determine treatment effects among weeks. Precalving BCS altered the inflammatory state of neutrophils, with significant increases

\footnotetext{
Received October 4, 2016.

Accepted November 28, 2016.

${ }^{1}$ Corresponding author: mallory.crookenden@dairynz.co.nz

${ }^{2}$ Current address: Growing Up in New Zealand, University of Auckland, Auckland 1072, New Zealand.
}

in overall gene expression of antimicrobial peptides (BNBD4 and DEFB10) and the anti-inflammatory cytokine $I L 10$, and significantly decreased expression of proinflammatory cytokine IL23A in thinner cows (BCS 4) compared with cows calving at BCS 5. Feeding level had a time-dependent effect on gene expression; for example, increased expression of genes involved in leukotriene synthesis (PLA2G4A and ALOX5AP) occurred only at 1 wk postcalving in cows overfed $(125 \%$ of requirements) precalving compared with those offered $75 \%$ of maintenance requirements. Results indicate that precalving body condition and changes in prepartum energy lead to altered gene expression of circulating neutrophils, highlighting the importance of transition cow nutrition for peripartum health.

Key words: peripartum, nutrition, polymorphonuclear leukocyte, dairy cow

\section{INTRODUCTION}

A dairy cow undergoes several homeorhetic adaptations to facilitate the challenges associated with calving and the onset of lactation (Bauman and Currie, 1980; Goff and Horst, 1997). Failure to successfully adapt to this transition leads to reduced productivity and increased incidence of disease (Ingvartsen et al., 2003). Ultimately, this leads to reduced longevity and has a considerable effect on the dairy industry. For example, Godden et al. (2003) reported that $20 \%$ of cows culled annually left the herd in the first 3 wk postcalving. Furthermore, an estimated 30 to $50 \%$ of dairy cows are affected by metabolic or infectious disease during the transition period (LeBlanc, 2010).

Immune function is altered during the transition period, which may contribute to the increased risk of health disorders (Detilleux et al., 1995; Mallard et al., 1998; Crookenden et al., 2016). It is increasingly evi- 
dent that prepartum nutrition and nutrient availability play an important role in the successful transition of dairy cows; for example, BCS and level of feeding affect indicators of health and metabolic function during the transition period (Roche et al., 2005, 2013, 2015; Douglas et al., 2006; Loor et al., 2006). Roche et al. $(2009,2013)$ reported that cows calving at a BCS 4.5 to 5.0 (10-point scale) had a superior health profile to those calving at either 3.5 or 5.5. Similarly, improvements in markers of health [e.g., blood nonesterified fatty acids (FA), BHB, liver triacylglycerol (TAG), and markers of inflammatory state] have been reported when cows were fed 75 to $90 \%$ of their ME requirements before calving compared with cows consuming energy in excess of requirements (Douglas et al., 2006; Loor et al., 2006; Roche et al., 2015). Little information is available on the effect of precalving BCS and feeding level on the state of the immune system despite a link between nutrition and immune function (Sordillo and Aitken, 2009; Sordillo and Mavangira, 2014), but it is conceivable that precalving nutrition could affect gene expression of immune cells during the transition period. Many studies investigating immune function during the peripartum period have focused on neutrophils, primarily because of their role in pathogen destruction during infection (Nagahata et al., 1988; Mallard et al., 1998; Kimura et al., 2014). The ability of neutrophils to function effectively has been related to the incidence of peripartum-related diseases, including mastitis, displaced abomasum, and retained placenta (Goff and Horst, 1997; Burton et al., 2001; Kimura et al., 2002; LeBlanc, 2008, 2010; Cardoso et al., 2013). Increasing evidence supports the hypothesis that prepartum nutrition state affects neutrophil function (Graugnard et al., 2012; Moyes et al., 2014; Zhou et al., 2015). For example, the severity of negative energy balance (NEB) during early lactation contributes to the degree of immune suppression and susceptibility to disease during the peripartum period (Goff, 2006). The expression of genes involved in the immune response of neutrophils to an intramammary infection is also affected by NEB (Moyes et al., 2010). Furthermore, dietary energy during the prepartum period affects the expression of neutrophil inflammatory mediators (Zhou et al., 2015). Therefore, identifying a nutritional regimen that will positively influence neutrophil function may reduce susceptibility of cows to disease during the transition period. The objectives of this study were to compare (1) the effect of precalving BCS and (2) the effect of under- and overfeeding of cows precalving on the transcriptional profile of neutrophils during the transition period.

\section{MATERIALS AND METHODS}

\section{Animal Handling and Experimental Design}

The Ruakura Animal Ethics Committee (Hamilton, New Zealand) approved all animal manipulations in accordance with the Ministry of Primary Industries (1999). The experiment was undertaken at Scott Farm, Hamilton, New Zealand $\left(37^{\circ} 46^{\prime} \mathrm{S} 175^{\circ} 18^{\prime} \mathrm{E}\right)$ between January and October 2013 using New Zealand Holstein-Friesian and Holstein-Friesian $\times$ Jersey cross dairy cows.

Comprehensive details of the experiment and animal management are described in Roche et al. (2015). Briefly, a total of 150 cows were allocated to 1 of 6 treatment groups (25 cows per group) matched for age, expected calving date, and breed in a $2 \times 3$ factorial arrangement. Cows were managed during mid and late lactation and from dry off to $21 \mathrm{~d}$ before predicted calving date to achieve the 2 precalving BCS treatment groups: BCS 4.0 and 5.0 on a 10-point scale, equivalent to approximately 2.75 and 3.25 , respectively, on a 5-point scale (Roche et al., 2004). From $-23 \pm 5.6$ d relative to expected calving until parturition, cows received fresh pasture at 3 levels of energy intakes $(75$, 100 , or $125 \%$ ) based on estimated $\mathrm{ME}$ requirements (1.05 MJ/kg of metabolic BW; Roche et al., 2005). Postcalving, all cows grazed together and were offered a diet of fresh pasture (average DMI $=12.4 \pm 0.8 \mathrm{~kg} / \mathrm{d}$ ), corn silage (average DMI $=0.8 \pm 0.8 \mathrm{~kg}$ of $\mathrm{DM} / \mathrm{d}$ ), and pasture silage (average DMI $=1.1 \pm 1.0 \mathrm{~kg}$ of DM/d) as supplementary feeds. Three treatment groups from the parent experiment were selected to investigate the effect of precalving BCS and prepartum feeding level on neutrophil gene expression: BCS 4 offered $75 \%$ and BCS 5 offered $75 \%$ (underfed), and BCS 5 offered $125 \%$ (overfed).

\section{Blood Sampling}

Blood ( $\sim 50 \mathrm{~mL} / \mathrm{cow})$ was sampled for neutrophil isolation and metabolite analysis $(\sim 10 \mathrm{~mL} / \mathrm{cow})$ at 5 time points over the transition period: precalving $(-1$ wk), day of calving (d 0), and postcalving at wk 1, 2, and 4. Blood for neutrophil isolation was collected in 6 evacuated blood tubes (BD, Auckland, New Zealand) containing acid citrate dextrose (solution A; trisodium citrate $22.0 \mathrm{~g} / \mathrm{L}$, citric acid $8.0 \mathrm{~g} / \mathrm{L}$, dextrose $24.5 \mathrm{~g} / \mathrm{L}$ ). Tubes were inverted 8 times and placed immediately on ice until neutrophil isolation, which occurred within $2 \mathrm{~h}$ of blood collection. Blood for metabolite analysis was collected in evacuated blood tubes containing a 
lithium heparin anticoagulant, inverted, and placed immediately on ice; within $30 \mathrm{~min}$, blood tubes were centrifuged at $1,500 \times g$ for $12 \mathrm{~min}$ at $4^{\circ} \mathrm{C}$, plasma aspirated, and stored at $-20^{\circ} \mathrm{C}$ until assayed.

\section{Liver Sampling for TAG Analysis}

Liver tissue samples were collected from all cows by biopsy the week before calving (wk -1) and on wk 1,2 , and 4 postcalving. Briefly, the skin was shaved and disinfected and the area anesthetized with $7 \mathrm{~mL}$ of $2 \%$ lignocaine (Lopaine 2\%, lignocaine hydrochloride $20 \mathrm{mg} / \mathrm{mL}$, Ethical Agents, South Auckland, New Zealand). An incision was made through the skin in the right 11th intercostal space at the level of the greater trochanter, through which a 12-gauge $\times 20$-cm biopsy needle was inserted into the liver and approximately $1 \mathrm{~g}$ (wet weight) of liver tissue was collected. Liver samples were snap-frozen in liquid nitrogen and stored at $-80^{\circ} \mathrm{C}$.

\section{Neutrophil Isolation}

Neutrophils were isolated from all cows according to procedures previously described (Crookenden et al., 2016). Blood collected in the acid citrate dextroseevacuated blood tubes was inverted and pooled (for each cow at each time point) by transfer into a $50-\mathrm{mL}$ conical tube. Tubes were centrifuged for $30 \mathrm{~min}$ at 850 $\times g$ at $4^{\circ} \mathrm{C}$. The plasma, buffy coat, and up to one-third of the red blood cells (RBC) were aspirated by Pasteur pipette and discarded, leaving two-thirds of remaining RBC and neutrophils. Water (milliQ, Millipore, New Zealand) was added $(25 \mathrm{~mL})$ and mixed for 10 to 30 $\mathrm{s}$ to lyse the RBC, and $5 \mathrm{~mL}$ of $5 \times$ concentrated PBS (pH 7.4, Life Technologies, Carlsbad, CA) was added to each tube to restore isotonicity. Tubes were spun at $330 \times g$ for 10 min at $4^{\circ} \mathrm{C}$ and supernatant decanted to isolate the white cell pellet. The pellet was washed with $10 \mathrm{~mL}$ of $1 \times$ concentrated PBS (pH 7.4, Life Technologies), vortexed, and centrifuged for $5 \mathrm{~min}$ at $660 \times g$ at $4^{\circ} \mathrm{C}$. If $\mathrm{RBC}$ remained, the water-lysing step was repeated. Cells were resuspended in $5 \mathrm{~mL}$ of $1 \times$ PBS $(\mathrm{pH}$ 7.4) and $100 \mu \mathrm{L}$ was transferred into a $1.5-\mathrm{mL}$ microcentrifuge tube (Raylab, Auckland, New Zealand) and placed on ice for subsequent viability and staining assays. The $50-\mathrm{mL}$ tubes were centrifuged again ( $5 \mathrm{~min}$ at $660 \times g$ at $\left.4^{\circ} \mathrm{C}\right)$, liquid decanted, and the cell pellet resuspended in $1 \mathrm{~mL}$ TRIzol reagent (Life Technologies). The 1-mL cell suspension was transferred to a 2-mL microcentrifuge tube (Eppendorf, Hamburg, Germany), placed immediately on ice, and stored at $-80^{\circ} \mathrm{C}$ for subsequent RNA extraction.

\section{Cell Differentials and Viability}

A subpopulation of isolated cells from randomly selected samples $(\mathrm{n}=41)$ was used to determine cell viability and neutrophil population by flow cytometry analysis using the BD FACS Aria II cell sorter (BD Biosciences, San Jose, CA). Viability was measured using LIVE/DEAD Fixable Blue Dead Cell Stain Kit (L23105, Life Technologies) and neutrophil populations were determined with the bovine granulocyte-specific primary monoclonal antibody CH138A (WS0608B-100, Kingfisher Biotech Inc., St. Paul, MN) and phycoerythrin-conjugated secondary antibody (SB102009S, Southern Biotech, Birmingham, AL). Neutrophils were gated based on CH138A-phycoerythrin fluorescence. Non-neutrophil granulocytes could be distinguished from neutrophils based on autofluorescence. Of total granulocytes isolated $(78.6 \pm 14.4 \%$, median $\pm \mathrm{SD})$ with this procedure, $93.4 \pm 7.9 \%$ (mean $\pm \mathrm{SD}$ ) were neutrophils and, of these, $93.3 \pm 10.2 \%($ mean \pm SD) were live cells.

\section{RNA Extraction}

Total RNA was extracted from all neutrophil samples using TRIzol reagent as per the manufacturers' instructions. Briefly, cell suspensions in TRIzol were homogenized using a PRO200 homogenizer (Pro Scientific, Oxford, CT); suspensions underwent two 20-s bursts of the homogenizer at full speed $(500 \mathrm{~Hz})$ and were placed on ice after every homogenization. The homogenizer tool was rinsed between each sample twice with $75 \%$ ethanol and water and once with RNaseZap (Life Technologies). Chloroform was added to the homogenized samples, and after centrifugation $(12,000 \times g$ for 15 $\min$ at $4^{\circ} \mathrm{C}$ ) the aqueous phase was carefully removed. Precipitation of RNA was achieved with the addition of isopropanol (Merck Millipore, Billerica, MA) and the subsequent RNA pellet was washed (with $75 \%$ ethanol), dried, and resuspended in UltraPure RNase/ DNase-free distilled water (Life Technologies). All RNA samples were DNase-treated using the Ambion DNAfree kit (Life Technologies). The quantity and purity of RNA was determined by spectrophotometry using a Nanodrop ND-1000 (Nanodrop Technologies, Wilmington, DE) and the RNA integrity number (RIN) was confirmed using an Agilent 2100 Bioanalyzer and RNA 6000 Nano LabChip kit (Agilent Technologies, Santa Clara, CA). Final sample sets $(\mathrm{n}=225 ; 15$ cows per treatment over 5 time points) based on whether samples from all 5 time points for each cow had sufficient quantity $(>2 \mu \mathrm{g})$ and quality (RIN $>7$ ) of RNA. Final neutrophil RNA samples had an average RIN (mean \pm 
SD) of $8.0 \pm 0.77$. Samples were stored at $-80^{\circ} \mathrm{C}$ until cDNA synthesis.

\section{Complementary DNA Synthesis and Primer Design}

Total RNA $(2 \mu \mathrm{g})$ from each sample was reverse transcribed using a Superscript III Supermix kit (Life Technologies), with random pentadecamer primers (Integrated DNA Technologies, Coralville, IA) at a final concentration of $27 \mu M$. Reverse-transcriptase negative controls were also generated by excluding the enzyme. Complementary DNA samples were stored at $-20^{\circ} \mathrm{C}$.

Assay design for 96 gene targets $[78$ genes involved in neutrophil function and 18 possible endogenous control genes chosen based on current literature (Crookenden et al., 2016); Supplemental Table S1, https://doi. org/10.3168/jds.2016-12105] for use in quantitative reverse transcription-PCR (qRT-PCR) was undertaken using publicly available bovine gene sequences from the National Center for Biotechnology Information gene database (NCBI; http://www.ncbi.nlm.nih.gov). Assays were designed to span an intron-exon boundary, where possible, using Roche Universal Probe Library (UPL) design software (Roche, Basel, Switzerland). Primer sequences were verified by BLAST and PrimerBLAST analysis (NCBI) to ensure specificity. Assays were tested on a LightCycler 480 instrument (Roche). Each qRT-PCR reaction contained custom designed forward and reverse primers (200 $\mathrm{n} M$, Integrated DNA Technologies), UPL unique probe (50 nM, Roche), LightCycler480 Probes Master $(1 \times$ concentration), and RNase/DNase-free distilled water. Standard cycling conditions were used $\left[95^{\circ} \mathrm{C}\right.$ for $10 \min \left(95^{\circ} \mathrm{C}\right.$ for $10 \mathrm{~s}$, $60^{\circ} \mathrm{C}$ for $\left.30 \mathrm{~s}\right) \times 50$ cycles, $40^{\circ} \mathrm{C}$ for $40 \mathrm{~s}$ ]. To test assays, a 6-point 10-fold standard curve was generated from a $1 \times$ dilution (1:4 dilution of raw cDNA) to $1 \times 10^{-6}$ dilution. To ensure a single product free of genomic DNA contamination and to verify the amplicon size, reactions positive for gene expression as well as $\mathrm{H}_{2} \mathrm{O}$ negative controls were verified with gel electrophoresis.

\section{Gene Expression}

Expression of genes involved in neutrophil function was quantified using qRT-PCR using the BioMark HD real-time PCR system (Ramaciotti Centre, Randwick, NSW, Australia). Microfluidics 96.96 Dynamic Array (Fluidigm, San Francisco, CA) integrated fluidic circuit chips combined with Roche UPL chemistry were used to generate expression results for 96 gene targets for all samples $(\mathrm{n}=225)$. A preamplification of $\mathrm{cDNA}$ was undertaken to create target-specific amplified reactions by multiplexing forward and reverse primers $(200 \mathrm{n} M)$ of the 96 assays with the following cycling protocol; $95^{\circ} \mathrm{C}$ for $10 \mathrm{~min}\left(95^{\circ} \mathrm{C}\right.$ for $15 \mathrm{~s}$, and $60^{\circ} \mathrm{C}$ for $\left.4 \mathrm{~min}\right)$ by 14 cycles. Assay mixtures, including forward and reverse primers $(800 \mathrm{n} M)$, Roche UPL probes $(100 \mathrm{n} M)$, and $2 \times$ concentration assay loading reagent (Fluidigm) were combined with $1 \times$ concentration Roche LightCycler480 Probes Master (Roche) and 20× gene expression sample loading reagent (Fluidigm) on a 96.96 gene expression chip (Fluidigm) for use in the BioMark HD instrument. The gene expression cycling protocol, GE $96 \times 96$ UPL v1.pcl (BioMark HD Data Collection software v3.0.2), was used to generate crossing point (Cp) values: $70^{\circ} \mathrm{C}$ for $30 \mathrm{~min}, 25^{\circ} \mathrm{C}$ for $10 \mathrm{~min}, 95^{\circ} \mathrm{C}$ for $1 \mathrm{~min}$, followed by 35 cycles of $96^{\circ} \mathrm{C}$ for $5 \mathrm{~s}$ and $60^{\circ} \mathrm{C}$ for $20 \mathrm{~s}$.

Possible endogenous control genes were tested across all samples using GeNorm (Vandesompele et al., 2002) and NormFinder (Andersen et al., 2004) software. A 5 -point standard curve was included ( 3 -fold serial dilutions from $3.33 \times 10^{-1}$ to a final dilution of $4.12 \times 10^{-3}$ ) to calculate the qRT-PCR efficiency for all 96 genes. Of the 18 endogenous control genes tested, RPL19 and $Y W H A Z$ were chosen as the 2 endogenous control genes for this neutrophil study. The NormFinder stability of the combination of these 2 genes was 0.072 and the GeNorm stability values $(\mathrm{M})$ were $<0.58$ for both genes, with little improvement in stability with the addition of a third endogenous control gene.

Relative quantification was achieved using the $\Delta \mathrm{Cp}$ method; the geometric mean of the $\mathrm{Cp}$ values of the endogenous control genes was calculated and target assay $\mathrm{Cp}$ values were made relative to the geometric mean of endogenous controls $(\Delta \mathrm{Cp})$. Fold change $(\Delta \Delta \mathrm{Cp})$ relative to BCS 5 was calculated as

$$
\begin{aligned}
& \text { Fold change }= \\
& \text { qPCR efficiency } y_{\text {gene of interest }}(\Delta \mathrm{Cp} \mathrm{BCS} 5-\Delta \mathrm{Cp} \mathrm{BCS} 4) \text {. }
\end{aligned}
$$

The fold change calculation for the effect of overfeeding (125\% of estimated ME requirements) relative to feeding $75 \%$ of estimated ME requirements was calculated as

$$
\begin{aligned}
& \text { Fold change }= \\
& \text { qPCR efficiency gene of interest }\left(\Delta \mathrm{Cp} 75 \%-\Delta \mathrm{Cp}^{125 \%)}\right. \text {. }
\end{aligned}
$$

\section{Metabolite Analysis}

Blood metabolite and liver TAG assays were undertaken by Gribbles Veterinary Pathology Ltd. (Hamilton, New Zealand). Full details of blood metabolite analysis are described in Roche et al. (2015). Briefly, 
blood metabolites were assayed using colorimetric techniques at $37^{\circ} \mathrm{C}$ with a Hitachi Modular P800 analyzer (Roche). Roche reagent kits were used to measure plasma concentrations of albumin $(\mathrm{g} / \mathrm{L})$, BHB (mmol/L), $\mathrm{Ca}(\mathrm{mmol} / \mathrm{L}), \mathrm{Mg}(\mathrm{mmol} / \mathrm{L})$, and total protein $(\mathrm{g} / \mathrm{L})$. Plasma globulin was calculated as the difference between total protein and albumin. Plasma FA concentrations $(\mathrm{mmol} / \mathrm{L})$ were measured using Wako Chemicals kit (Osaka, Japan). Interleukins (IL-1 $\beta$ and IL-6) and haptoglobin were analyzed by commercial bovine ELISA kits (Pierce, Thermo Scientific, Waltham, MA; GenWay Biotech Inc., San Diego, CA; and Life Diagnostics Inc., West Chester, PA). Cholesterol and total antioxidant capacity were also measured using commercially available kits (10007640 and 709001, respectively, Cayman Chemical Company, Ann Arbor, MI). Reactive oxygen species (ROS) were measured using a commercially available fluorometric kit (STA-342, Cell Biolabs Inc., San Diego, CA). Liver TAG content was analyzed in biopsy samples (wk 1, 2, and 4 postcalving) using the standard procedure provided in the Wako LabAssay TM Triglyceride Kit (290-63701, Wako Chemicals USA Inc., Richmond, VA).

\section{Statistics}

All variables (gene expression and metabolites) were subjected to repeated measures ANOVA to assess the effect of treatment and treatment effects over time, using a mixed models approach (PROC Mixed, SAS 9.3, SAS Institute Inc., Cary, NC) that included the fixed effects of treatment (precalving BCS and feeding level), week, and their interaction, and cow as a random effect. The model for gene expression also included the Microfluidics 96.96 Dynamic Array (Fluidigm) chip as a blocking factor, wwhereashile the models for metabolites and production, where possible, included covariate data from the end of the previous lactation. Metabolite

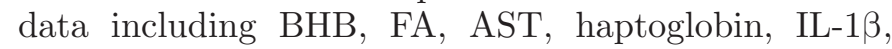
IL-6, and ROS were $\log _{10}$-transformed to achieve homogeneity of variance. Positively skewed variables were $\log _{10}$-transformed, variables with negatively skewed distribution were reflected and $\log _{10}$-transformed. If the effect of time was significant $(P<0.05)$, Tukey's $t$-test was used for pairwise comparisons among weeks. Statistical significance was considered at $P \leq 0.05$ and a trend was considered when $P \leq 0.10$. Results are presented as LSM with standard error of the difference (SED).

\section{RESULTS AND DISCUSSION}

Gene expression results from 96 genes were generated; however, results presented are limited to those that tended $(P<0.10)$ to be or were significantly $(P \leq$ 0.05 ) altered by either BCS (Figure 1) or feeding level (Figure 2). Genes that indicated an interaction between feeding level and time relative to calving (week) are also presented. With the exception of $A B C A 1$, no significant interactions were found between BCS and week. We have previously reported temporal changes in the neutrophil transcriptional phenotype in grazing dairy cows across the calving period (Crookenden et al., 2016). Briefly, the expression of genes involved in neutrophil adhesion and migration, mediation of the immune response, neutrophil lifespan, and antimicrobial action, were differentially expressed over the transition period. These changes were consistent with previous reports of peripartum changes in neutrophil function, wherein oxidative burst metabolism, random migration, and phagocytosis were perturbed over the calving period (Kehrli et al., 1989; Detilleux et al., 1995). In the current study, both precalving BCS and precalving feeding level affected the transcriptional regulation of the neutrophil genes previously investigated (Crookenden et al., 2016). However, the effect of precalving feeding level on the neutrophil transcriptional phenotype was time-dependent. These results indicate a potential role for precalving diet to modify the peripartum changes in neutrophil function and the timing at which these cells return to normal function after calving.

\section{Precalving BCS and Abundance of Genes Involved in Neutrophil Function}

The presented genomic phenotype indicates an increase in the bactericidal capacity and a reduction in the inflammatory state of circulating neutrophils in BCS 4 cows. Compared with BCS 5 cows, the expression of the defensins, BNBD4 (1.9 fold), DEFB10 (2.6 fold), and $S 100 A 9$ (1.2 fold), increased significantly ( $P$ $<0.05)$ overall in BCS 4 cows, and we noted a trend $(P$ $=0.09$ ) for increased $D E F B 1$ (2.3 fold) expression, over the 5 -wk period that blood samples were collected (Figure 1). Defensins are small cationic polypeptides with antimicrobial and immunomodulatory activity that have been identified in a wide variety of cell types and in many different species, including bovine neutrophils (Selsted et al., 1996; Ganz, 2003). The increased expression of these antimicrobial peptides in BCS 4 cows relative to their fatter counterparts probably indicates an increased capacity of neutrophils from these animals to destroy pathogens (Kaiser and Diamond, 2000). An association between defensin concentration in plasma and adiposity has also been reported in humans, although the direction of the association is not consistent and is likely due to the differences in the tissue of origin of the circulating defensins. For example, in a study 
investigating cardiovascular disease risk factors, LópezBermejo et al. (2007) presented results consistent with those reported here; individuals in the upper quartile of plasma defensin concentrations were leaner and experienced a greater sensitivity to insulin. López-Bermejo et al. (2007) claimed that this association reflected superior metabolic health. Conversely, another study demonstrated that $\alpha$-defensin gene expression in human plasma was greater in obese patients, with lower expression after bariatric or weight loss surgery (Manco et al., 2010). Plasma defensins are pathologically different from those in immune cells and human $\alpha$-defensins are distinct from bovine $\beta$-defensins (Luenser and Ludwig, 2005). However, this indicates that these peptides may be indicative of immunological alterations to metabolic change and reflect changes in expression in cases of unbalanced inflammation (e.g., cardiovascular disease or with changes in adiposity). Furthermore, the greater expression of $S 100 A 9$ in neutrophils from BCS 4 cows indicates increased antimicrobial capacity, as
BNBD4

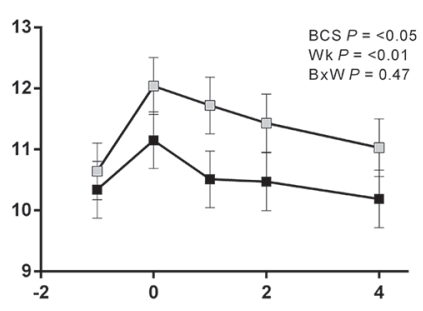

DEFB1

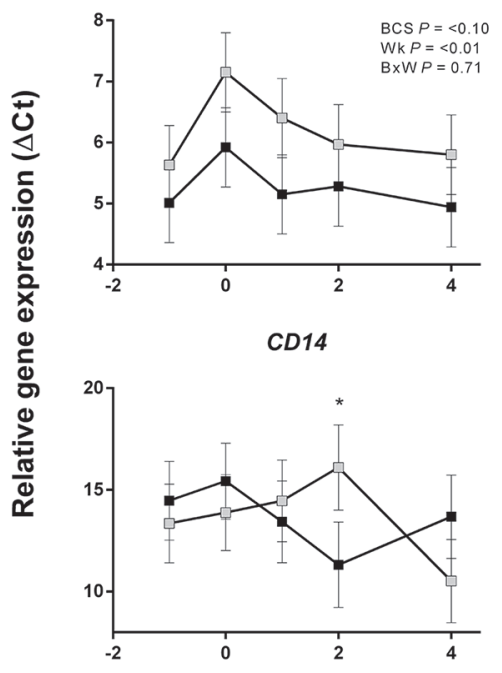

MMP8

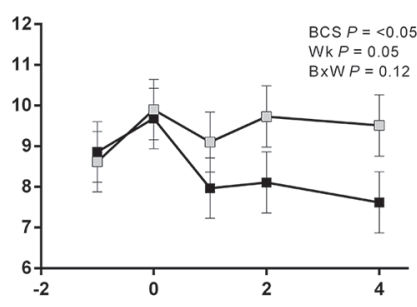

$\rightarrow \operatorname{BCS} 4 \rightarrow \operatorname{BCS} 5$

DEFB10

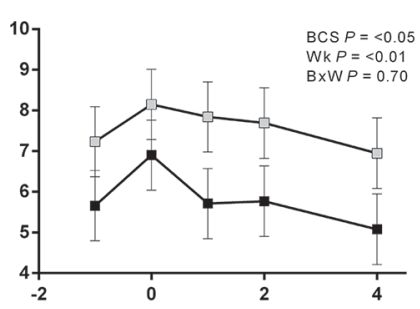

ABCA1
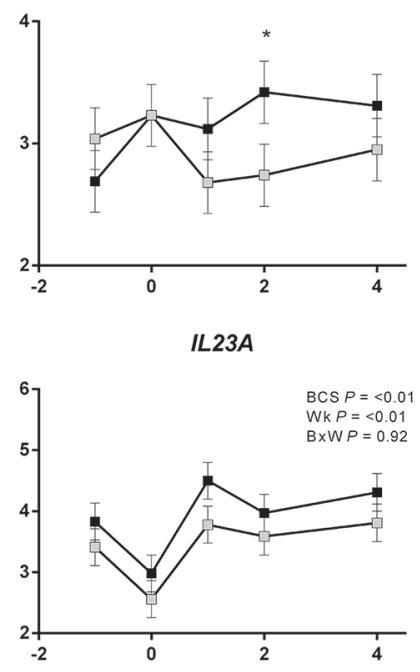

MMP9

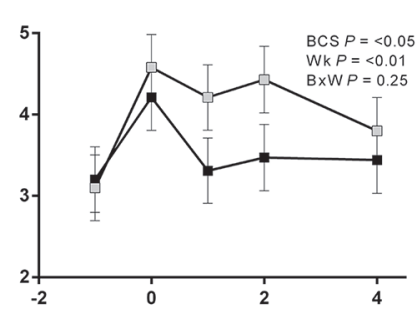

Week relative to calving (0)

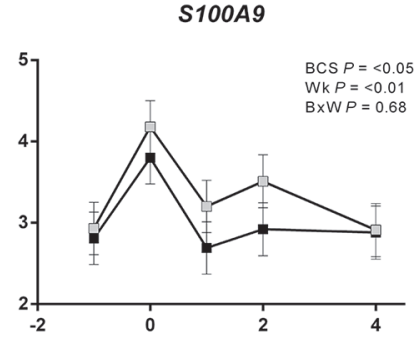

ALOX5AP
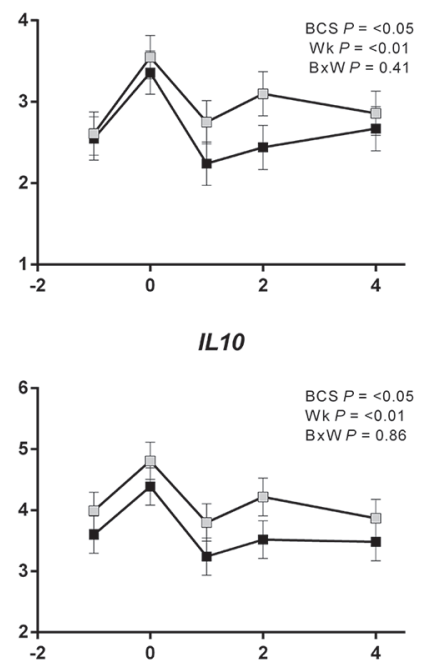

KIT

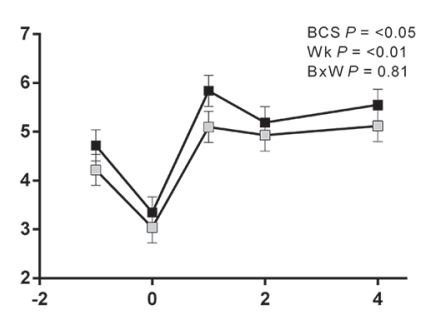

Figure 1. Relative gene expression $(\Delta \mathrm{Ct})$ of neutrophils isolated from BCS 4 (under-conditioned, $\mathrm{n}=15$; gray squares) and BCS 5 (adequately conditioned, $\mathrm{n}=15$; black squares) cows over the transition period. Values are expressed as LSM \pm standard error of the difference. Statistical significance was calculated using repeated measures ANOVA. The $P$-value for treatment (BCS) and time point (week) and the interaction of treatment and time point $(\mathrm{B} \times \mathrm{W})$ are only displayed on the graphs where no significant interaction occurred $(P>0.05)$. For genes with a significant interaction $(P<0.05)$, significant differences between means are denoted with an asterisk $(*)$. 


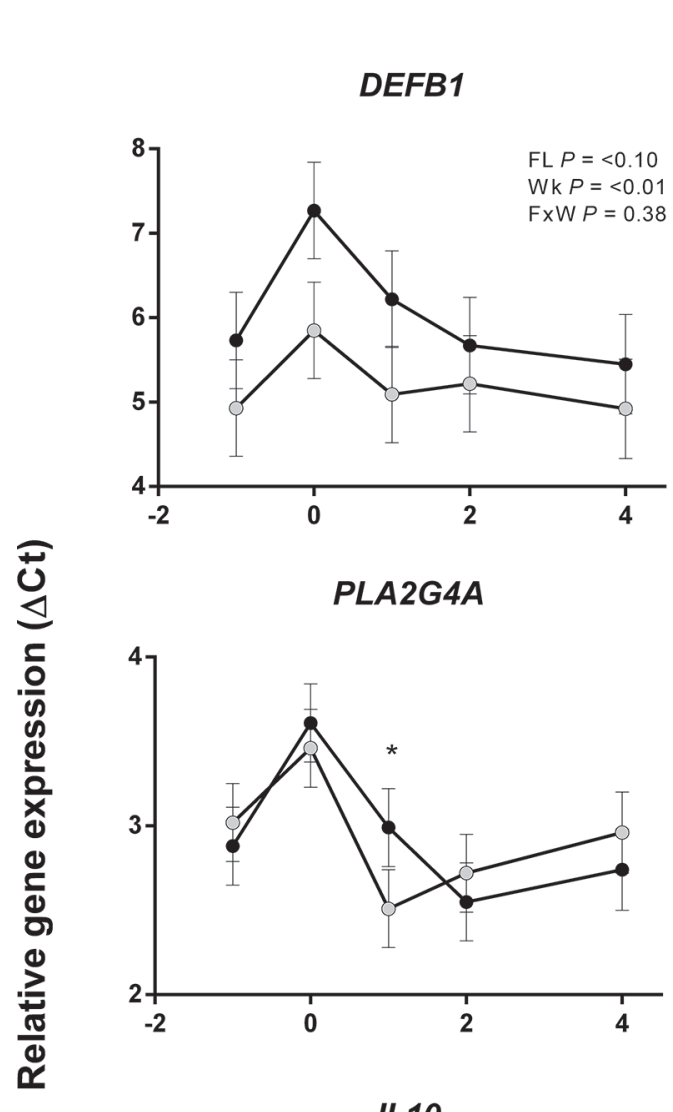

IL10

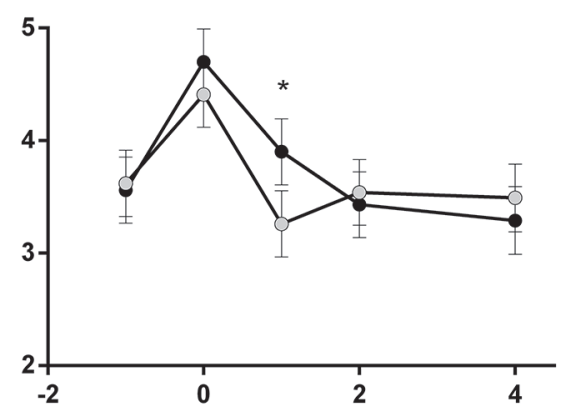

$\multimap 75 \% \multimap 125 \%$

S100A9

ALOX5AP

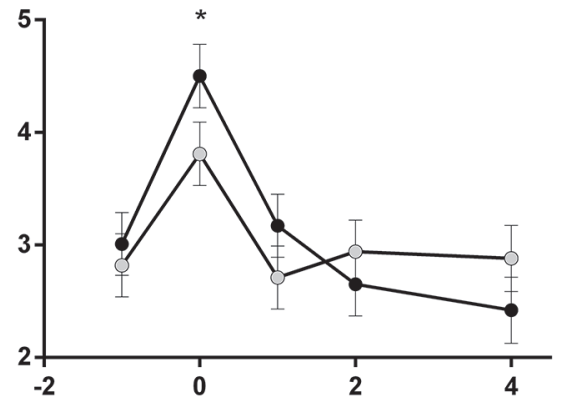

CD121B

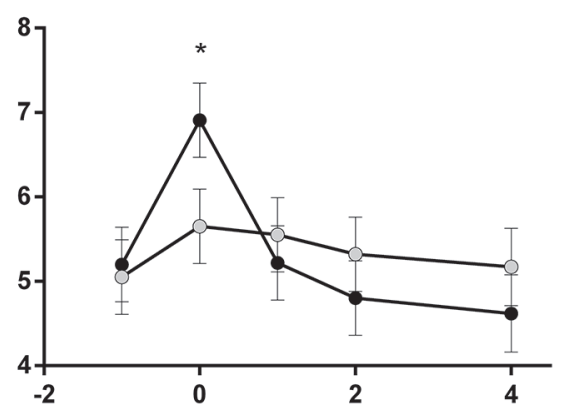

STAT3
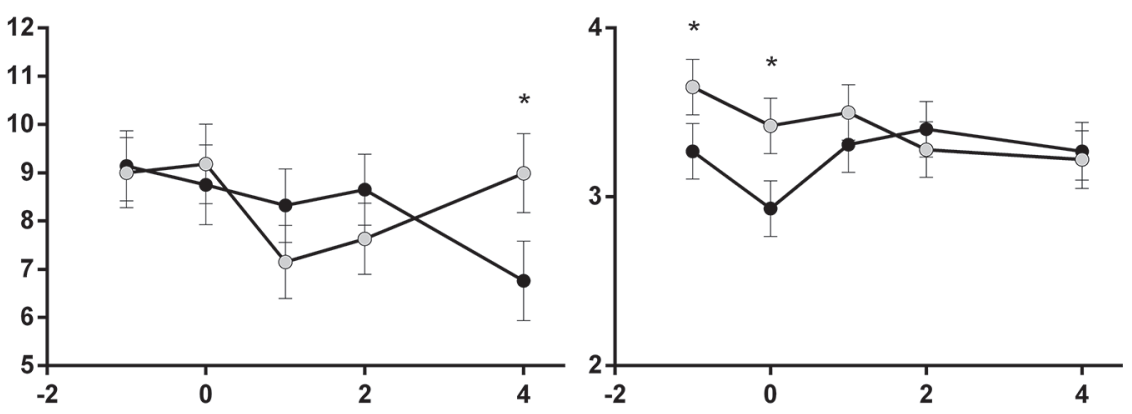

Week relative to calving (0)

Figure 2. Relative gene expression $(\Delta \mathrm{Ct})$ of neutrophils isolated from underfed ( $75 \%$ of maintenance requirements, $\mathrm{n}=15 ;$ gray circles) and overfed $(125 \%$ of maintenance requirements, $\mathrm{n}=15$; black circles) cows during the transition period. Values are expressed as LSM \pm standard error of the difference. Statistical significance was calculated using repeated measures ANOVA. The $P$-value for treatment (feeding level, FL) and time point (week) and the interaction of treatment and time point $(\mathrm{F} \times \mathrm{W})$ are only displayed on the graphs where there was no significant interaction $(P>0.05)$. For genes with a significant interaction $(P<0.05)$, significant differences between means are denoted with an asterisk $(*)$ and a trend $(P<0.10)$ is denoted with a cross $(\dagger)$.

the S100A9 enzyme is involved in the production of $\mathrm{H}_{2} \mathrm{O}_{2}$, a respiratory burst product for the destruction of pathogens (Bréchard et al., 2013). The gene expression changes in response to precalving BCS indicate an association between adiposity and inflammation and suggest a reduced inflammatory state in thinner animals; however, further work is required to determine if this relationship is quadratic and, if so, to define the turning point indicative of optimum immunological function.

Precalving BCS also altered the expression of several genes involved in mediating the immune response in neutrophils, indicating a shift to a less proinflammatory state in BCS 4 cows. For example, expression of IL10, 
$M M P 8$, and $M M P 9$ was greater in BCS 4 cows, on average, whereas expression of IL23A, KIT, and RPL23 was less overall in BCS 4 cows compared with BCS 5 cows (Figure 1). Interleukin-10 is an anti-inflammatory cytokine required for the resolution of the inflammatory response (Couper et al., 2008). In comparison, IL-23 has an important role in regulating the production of inflammatory cytokines and is involved in maintaining neutrophil homeostasis and granulopoiesis (Stark et al., 2005). Matrix metalloproteinases MMP-8 and MMP-9 (neutrophil collagenase and gelatinase, respectively) are required for neutrophil migration, and their activity and regulation are critical for recruitment to tissue (e.g., mammary gland tissue in cases of mastitis; Matrisian, 1990; Li et al., 1999). The increased expression of enzymes that are critical for neutrophil migration may indicate a greater capacity for these cells to be recruited into tissue in BCS 4 cows.

The changes in the inflammatory phenotype in BCS 4 cows may be a result of the reduced adiposity in these cows, as adipose tissue is proinflammatory in nature (Vailati-Riboni et al., 2016). The current study demonstrates evidence of altered cholesterol utilization in response to BCS; compared with BCS 5 cows, we noted an increase (1.5 fold, $P<0.05)$ in $A L O X 5 A P$ gene expression in thinner cows. The protein product of $A L$ OX 5AP associates with 5-lipoxygenase for the synthesis of leukotrienes. Furthermore, an interaction occurred between BCS and week on expression of $A B C A 1$ due to a significant decrease in expression in BCS 4 cows 2 wk postcalving. The ABCA1 cholesterol efflux transporter is regulated by the concentration of cholesterol in the cell; decreased expression, therefore, suggests an increase in cellular cholesterol, which could be used for subsequent cellular processes, such as cell membrane maintenance or prostaglandin and leukotriene synthesis. Combined with an increased expression of ALOX5AP, the lower expression of $A B C A 1$ may indicate an increase in proinflammatory leukotrienes (Funk, 2001) at wk 2 postcalving in BCS 4 cows. Concomitant increased expression of PLA2G4A and ALOX5 did not occur, however, which would have been expected if there was activation of the leukotriene synthesis pathway. The expression results, therefore, cannot confirm increased prostaglandin or leukotriene synthesis in neutrophils of BCS 4 cows, but indicate altered utilization of intracellular cholesterol that is consistent with a reduction in peripheral adipose tissue.

Body condition score-associated changes in indicators of metabolic function were consistent with changes in neutrophil gene expression. Concentrations of FA, BHB, and albumin in plasma as well as TAG in liver were significantly $(P<0.01)$ less in BCS 4 cows after calving, and plasma globulin concentrations were sig- nificantly $(P<0.01)$ greater; albumin-to-globulin ratio was also less (Table 1). These changes in metabolic factors are consistent with previous reports on the effect of precalving BCS differences on indicators of health (Roche et al., 2013), and increased concentrations of FA (in vitro) enhance neutrophil oxidative burst and reduce cell viability (Scalia et al., 2006). In comparison, Hoeben et al. (2000) described a negative association between BHB and FA concentrations and neutrophil function during the peripartum period, therein suggesting that these metabolic markers may be characteristic of impaired neutrophil function. Collectively, the results support a relationship between adiposity and an effect on immune cell function, which may be exploited to regulate peripartal neutrophil function. However, the direct link between neutrophil function and blood metabolites was not explored in the current study.

\section{Feeding Level and Transcript Abundance of Genes Involved in Neutrophil Function}

Precalving feeding level affected neutrophil gene expression, but the effect was time-dependent. For example, the expression of genes involved in leukotriene synthesis, PLA2G4A and ALOX5AP, was significantly $(P<0.05)$ greater in overfed cows compared with underfed cows, but only at 1 wk postcalving (Figure 2). This possibly indicates increased leukotriene synthesis in the neutrophils of overfed cows and, therefore, a greater degree of inflammation than in cows underfed during the precalving period. Similarly, the effect of precalving feeding level on the expression of other genes involved in inflammatory pathways (e.g., CD121B, CD44, IL10, and STAT3) was dependent on the time point during the transition period. Overfed cows, fed $125 \%$ of maintenance requirements, had greater expression of $C D 121 B$ on the day of calving and increased expression of $I L 10$ at $1 \mathrm{wk}$ postcalving when compared with underfed cows consuming $75 \%$ of ME requirements. The enzyme phospholipase A2, encoded by PLA2G4A, hydrolyzes phospholipids for the production of arachidonic acid. Arachidonic acid is subsequently metabolized into eicosanoids, which are proinflammatory lipid-signaling leukotriene molecules (e.g., leukotriene $\mathrm{B}_{4}$ ) by the enzyme 5-lipoxygenase (encoded by the $A L O X$ gene) and 5-lipoxygenase-activating protein (FLAP, encoded by ALOX5AP; Funk, 2001). Consistent with our results, there was also an increased expression of ALOX5AP and PLA2G4A in the neutrophils of cows with increased level of prepartum feeding in grain-fed cows (Zhou et al., 2015); these cows also demonstrated altered neutrophil function that indicated a state of chronic inflammation (Zhou et al., 2015). Further evidence of increased inflammation in overfed cows is the 
CROOKENDEN ET AL.

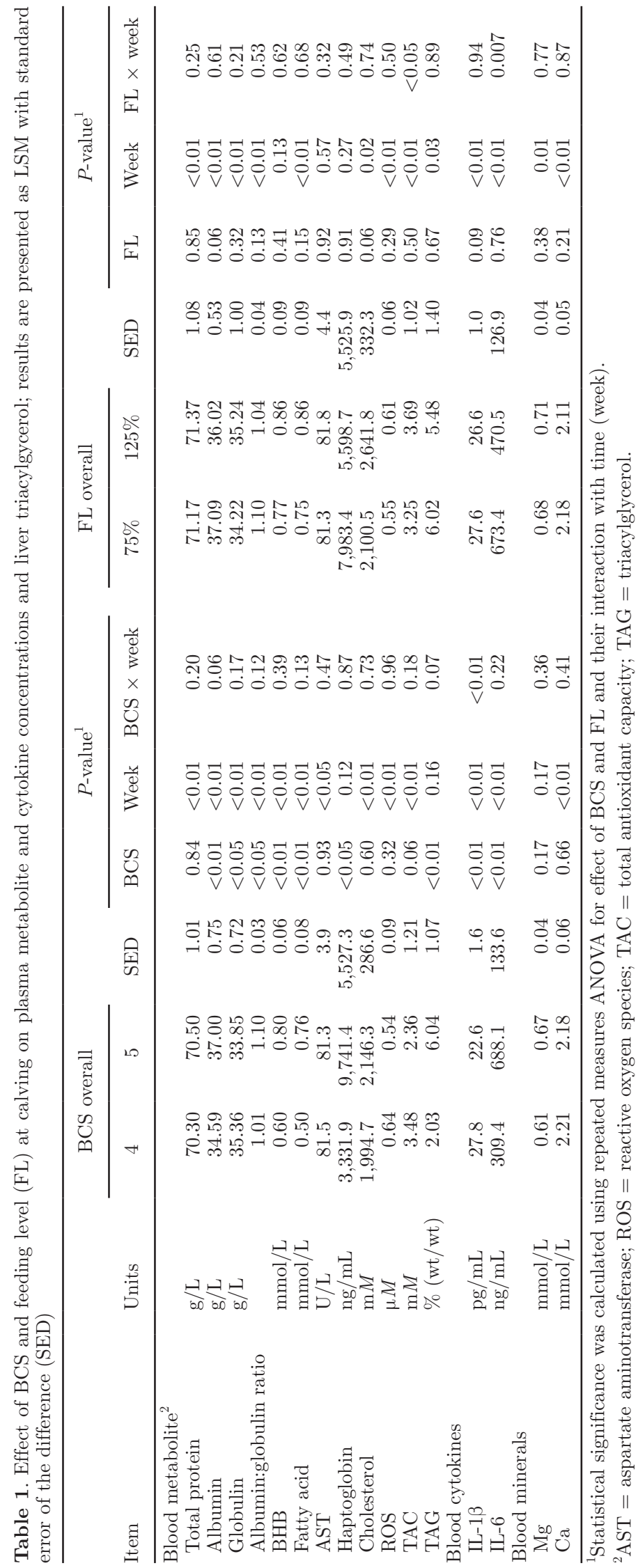


increased expression of S100A9; however, this effect was only evident on the day of calving in our study. Moyes et al. (2014) also noted an increase in S100A9 expression in the neutrophils of cows overfed TMR during the dry period. These results indicate that the effects of prepartum overfeeding in pasture-fed cows in the current study are similar to the immunological effects of overfeeding in conventionally housed, TMR-fed cows, and support findings of an increased inflammatory state of neutrophils in overfed cows.

The effect of feeding level on neutrophil activation early postpartum may be affected by greater circulating FA and plasma BHB concentration. A feeding level of $125 \%$ of maintenance requirements did not affect plasma FA or BHB compared with cows offered $75 \%$ of maintenance requirements $(P>0.1)$; however, we observed a numerical difference, with overfed animals having greater FA and BHB (Table 1), which is consistent with other studies that have investigated the effect of precalving energy intake on postcalving metabolism (Bertics et al., 1992; Roche et al., 2005; Douglas et al., 2006; Roche, 2007). In vitro investigation into the link between plasma FA concentrations and neutrophil function has indicated that high concentrations of FA $(>2 \mathrm{~m} M)$ increased generation of ROS, reduced neutrophil viability, and increased neutrophil necrosis (Scalia et al., 2006). The average concentrations of FA across all time points in the current study were 0.75 and $0.86 \mathrm{mmol} / \mathrm{L}$ in the 75 and $125 \%$ groups, respectively. Therefore, circulating FA concentrations were likely not high enough to considerably alter neutrophil gene expression. Collectively, the gene expression profiles demonstrate that precalving feeding level affects the neutrophil inflammatory state early postpartum and could potentially be used as a tool for immunomodulation in the transition cow.

\section{Limitations of the Experimental Design}

For the majority of genes investigated (61 of 78), gene expression was not different between the 2 precalving BCS groups and 2 feeding level treatments imposed (Supplemental Table S1; https://doi.org/10.3168/201612105). Rather than a lack of effect of either BCS or precalving feeding level, it is possible that the imposed treatments were not extreme enough to elicit changes in these physiological pathways (Table 2). In extreme cases of adipose deposition, (e.g., obesity), increased oxidative stress and elevated systemic inflammation interact with leukocytes and affect cell function (Chan et al., 2002; Fantuzzi, 2005; Manna and Jain, 2015). Obesity-related inflammation occurs because of changes in adipocyte metabolism as a result of increased adipose deposition (Gregor and Hotamisligil, 2011). Subacute inflammation during the transition period can be likened to obesity-related metabolic changes, as reviewed by Bradford et al. (2015). Deviation from the optimal calving BCS (5.0, 10-point scale; Roche et al., 2009) increases the risk of clinical pathologies; for example, over- and under-conditioned cows are at greater risk of mastitis (Kaneene and Miller, 1995). Cows with a calving $\mathrm{BCS}>5.5$ ( $>4$ on a 5 -point scale) experience a more severe NEB during the peripartal period and are at greater risk of metabolic and infectious diseases (Treacher et al., 1986; Stockdale, 2001; Ingvartsen, 2006; Roche et al., 2009, 2013), which is likely associated with a concurrent reduction in leukocyte function (Lacetera et al., 2005). Regarding the differential gene expression between the 2 feeding levels investigated here, research by Osorio et al. (2013) investigated the effect of overfeeding dams ( $120 \%$ of control diet) for $21 \mathrm{~d}$ precalving on calf neutrophils, demonstrating an increase in neutrophil oxidative burst and changes in neutrophil gene expression in calves born to overfed dams. However, the majority of gene expression changes attributed to treatment were at $2 \mathrm{~d}$ postcalving (Osorio et al., 2013). It is, therefore, possible that greater expression changes may have been evident in our study if we had collected postcalving samples closer to calving (i.e., $2 \mathrm{~d}$ vs. $1 \mathrm{wk}$ ). In cases of severe fasting or starvation in humans, negative effects on lymphocyte and neutrophil function have been observed, including decreased chemotaxis and microbial destruction (McMurray et al., 1990). In our study, the low-BCS and low-DMI treatments indicated possible improvements in neutrophil function. The natural variation in precalving BCS and feeding level that is common in pasture-based dairy herds will not likely adversely affect neutrophil function. However, more extreme states were not investigated, likely contributing to the small number of genes that were differentially expressed. This highlights that the points at which a low BCS and low DMI negatively affect immune function require further investigation.

\section{CONCLUSIONS}

The precalving BCS and precalving feeding levels evaluated demonstrated few differences in transcript abundance of the selected genes involved in neutrophil function. Nevertheless, results indicate a reduced inflammatory state of neutrophils and an enhanced capacity for microbial destruction in thinner cows, probably reflecting a negative effect of added body condition rather than support for under-conditioning transition cows. Furthermore, prepartum feeding level altered the inflammatory state of neutrophils during the peripartum period; however, this was dependent on 
Table 2. Effect of body condition (BCS) and feeding level (FL) at calving on the average production parameters during wk 1, 2, and 4 postcalving; results are presented as LSM with standard error of the difference (SED) and overall significance of treatment $(P$-value), as we found no interactions $(P>0.05)$ between $\mathrm{BCS} \times$ week and FL $\times$ week

\begin{tabular}{|c|c|c|c|c|c|c|c|c|c|}
\hline Parameter & Units & \multicolumn{2}{|c|}{ BCS overall } & SED & $\begin{array}{c}P \text {-value } \\
\text { BCS }\end{array}$ & \multicolumn{2}{|c|}{ FL overall } & SED & $\begin{array}{c}P \text {-value } \\
\text { FL }\end{array}$ \\
\hline $\begin{array}{l}\text { Milk weight } \\
\text { Composition }\end{array}$ & $\begin{array}{l}\mathrm{kg} \\
\%\end{array}$ & 20.36 & 23.39 & 1.05 & 0.01 & 23.52 & 23.91 & 1.02 & 0.71 \\
\hline Fat & & 4.43 & 4.64 & 0.16 & 0.21 & 4.77 & 4.95 & 0.18 & 0.33 \\
\hline Protein & & 3.74 & 3.65 & 0.09 & 0.33 & 3.67 & 3.70 & 0.09 & 0.65 \\
\hline Lactose & & 8.14 & 8.27 & 0.20 & 0.51 & 8.42 & 8.66 & 0.24 & 0.32 \\
\hline Protein & & 0.77 & 0.85 & 0.04 & 0.06 & 0.86 & 0.88 & 0.04 & 0.62 \\
\hline $\log _{10} \mathrm{SCC}$ & & 5.01 & 4.80 & 0.14 & 0.14 & 4.76 & 4.86 & 0.15 & 0.53 \\
\hline
\end{tabular}

the time relative to calving. Treatment groups were selected to represent the norm within optimally managed pasture-based herds and did not reflect extreme BCS and feeding level treatments. This may provide the reason for the limited number of observed differences in expression of neutrophil genes between treatments. Additional research is required to further elucidate the relationship between precalving BCS and prepartum energy intake and immune function throughout the transition period.

\section{ACKNOWLEDGMENTS}

The authors acknowledge farm staff (Scott Farm, DairyNZ) and, in particular, Jason Philips (farm manager). We also wish to acknowledge DairyNZ technical staff, Stu Morgan, Kate Watkins, Hamish Hodgson, and Chris Roach, for technical support and assistance with animal handling and sample collection. We acknowledge the statistical analysis and advice of Barbara Kuhn-Sherlock, DairyNZ. This work was supported by funding from New Zealand dairy farmers through DairyNZ Inc. (RD1403) and the Ministry of Business, Innovation and Employment (Wellington, New Zealand; DRCX1201).

\section{REFERENCES}

Andersen, C. L., J. L. Jensen, and T. F. Ørntoft. 2004. Normalization of real-time quantitative reverse transcription-PCR data: A model-based variance estimation approach to identify genes suited for normalization, applied to bladder and colon cancer data sets. Cancer Res. 64:5245-5250.

Bauman, D. E., and W. B. Currie. 1980. Partitioning of nutrients during pregnancy and lactation: A review of mechanisms involving homeostasis and homeorhesis. J. Dairy Sci. 63:1514-1529. https:// doi.org/10.3168/jds.S0022-0302(80)83111-0.

Bertics, S. J., R. R. Grummer, C. Cadorniga-Valino, and E. E. Stoddard. 1992. Effect of prepartum dry matter intake on liver triglyceride concentration and early lactation. J. Dairy Sci. 75:1914-1922. https://doi.org/10.3168/jds.S0022-0302(92)77951-X.
Bradford, B. J., K. Yuan, J. K. Farney, L. K. Mamedova, and A. J. Carpenter. 2015. Invited review: Inflammation during the transition to lactation: New adventures with an old flame. J. Dairy Sci. 98:6631-6650. https://doi.org/10.3168/jds.2015-9683.

Bréchard, S., S. Plançon, and E. J. Tschirhart. 2013. New insights into the regulation of neutrophil NADPH oxidase activity in the phagosome: A focus on the role of lipid and $\mathrm{Ca}(2+)$ signaling. Antioxid. Redox Signal. 18:661-676. https://doi.org/10.1089/ars.2012.4773.

Burton, J. L., S. A. Madsen, J. Yao, S. S. Sipkovsky, and P. M. Coussens. 2001. An immunogenomics approach to understanding periparturient immunosuppression and mastitis susceptibility in dairy cows. Acta Vet. Scand. 42:407-424.

Cardoso, F. C., S. J. LeBlanc, M. R. Murphy, and J. K. Drackley. 2013. Prepartum nutritional strategy affects reproductive performance in dairy cows. J. Dairy Sci. 96:5859-5871. https://doi. org $/ 10.3168 /$ jds.2013-6759.

Chan, J. C. N., J. C. K. Cheung, C. D. A. Stehouwer, J. J. Emis, P. C. Y. Tong, G. T. C. Ko, and J. S. Yudkin. 2002. The central roles of obesity-associated dyslipidemia. Int. J. Obes. 26:994-1008.

Couper, K. N., D. Blount, and E. Riley. 2008. IL-10: The master regulator of immunity to infection. J. Immunol. 180:5771-5777. https://doi.org/10.4049/jimmunol.180.9.5771.

Crookenden, M. A., A. Heiser, A. Murray, V. S. R. Dukkipati, J. K. Kay, J. J. Loor, S. Meier, M. D. Mitchell, K. M. Moyes, C. G. Walker, and J. R. Roche. 2016. Parturition in dairy cows temporarily alters the expression of genes in circulating neutrophils. J Dairy Sci. 99:6470-6483. https://doi.org/10.3168/jds.2015-10877.

Detilleux, J. C., M. E. Kehrli, J. R. Stabel, A. E. Freeman, and D. H. Kelley. 1995. Study of immunological dysfunction in periparturient Holstein cattle selected for high and average milk production. Vet. Immunol. Immunopathol. 44:251-267.

Douglas, G. N., T. R. Overton, H. G. Bateman, H. M. Dann, and J. K. Drackley. 2006. Prepartal plane of nutrition, regardless of dietary energy source, affects periparturient metabolism and dry matter intake in Holstein cows. J. Dairy Sci. 89:2141-2157. https://doi. org/10.3168/jds.S0022-0302(06)72285-8.

Fantuzzi, G. 2005. Adipose tissue, adipokines, and inflammation. J. Allergy Clin. Immunol. 115:911-919. https://doi.org/10.1016/j. jaci.2005.02.023.

Funk, C. D. 2001. Prostaglandins and leukotrienes: Advances in eicosanoid biology. Science 294:1871-1875. https://doi.org/10.1126/ science.294.5548.1871.

Ganz, T. 2003. Defensins: Antimicrobial peptides of innate immunity. Nat. Rev. Immunol. 3:710-720. https://doi.org/10.1038/nri1180.

Godden, S. M., S. C. Stewart, J. F. Fetrow, P. Rapnicki, R. Cady, W. Weiland, H. Spencer, and S. W. Eicker. 2003. The relationship between herd rBST-supplementation and other factors with risk for removal for cows in Minnesota Holstein dairy herds. Pages 55-64 in Proceedings of the Four-State Dairy Nutrition and Management Conference. MidWest Plan Service publication MWPS-4SD16, LaCrosse, WI. 
Goff, J. P. 2006. Major advances in our understanding of nutritional influences on bovine health. J. Dairy Sci. 89:1292-1301. https:// doi.org/10.3168/jds.S0022-0302(06)72197-X.

Goff, J. P., and R. L. Horst. 1997. Physiological changes at parturition and their relationship to metabolic disorders. J. Dairy Sci. 80:1260-1268. https://doi.org/10.3168/jds.S0022-0302(97)76055-

Graugnard, D. E., M. Bionaz, E. Trevisi, K. M. Moyes, J. L. SalakJohnson, R. L. Wallace, J. K. Drackley, G. Bertoni, and J. J. Loor. 2012. Blood immunometabolic indices and polymorphonuclear neutrophil function in peripartum dairy cows are altered by level of dietary energy prepartum. J. Dairy Sci. 95:1749-1758. https:// doi.org/10.3168/jds.2011-4579.

Gregor, M. F., and G. S. Hotamisligil. 2011. Inflammatory mechanisms in obesity. Annu. Rev. Immunol. 29:415-445. https://doi. org/10.1146/annurev-immunol-031210-101322.

Hoeben, D., E. Monfardini, G. Opsomer, C. Burvenich, H. Dosogne, A. D. E. Kruif, and J. Beckers. 2000. Chemiluminescence of bovine polymorphonuclear leucocytes during the periparturient period and relation with metabolic markers and bovine pregnancyassociated glycoprotein. J. Dairy Res. 67:249-259.

Ingvartsen, K. L. 2006. Feeding- and management-related diseases in the transition cow. Anim. Feed Sci. Technol. 126:175-213. https:// doi.org/10.1016/j.anifeedsci.2005.08.003.

Ingvartsen, K. L., R. J. Dewhurst, and N. C. Friggens. 2003. On the relationship between lactational performance and health: Is it yield or metabolic imbalance that cause production diseases in dairy cattle? A position paper. Livest. Prod. Sci. 83:277-308. https:// doi.org/10.1016/S0301-6226(03)00110-6.

Kaiser, V., and G. Diamond. 2000. Expression of mammalian defensin genes. J. Leukoc. Biol. 68:779-784.

Kaneene, J. B., and R. Miller. 1995. Risk factors for metritis in Michigan dairy cattle using herd- and cow-based modelling approaches. Prev. Vet. Med. 23:183-200. https://doi.org/10.1016/01675877(94)00438-O.

Kehrli, M. E., B. J. Nonnecke, and J. A. Roth. 1989. Alterations in bovine neutrophil function during the periparturient period. Am. J. Vet. Res. 50:207-214.

Kimura, K., J. P. Goff, P. Canning, C. Wang, and J. A. Roth. 2014. Effect of recombinant bovine granulocyte colony-stimulating factor covalently bound to polyethylene glycol injection on neutrophil number and function in periparturient dairy cows. J. Dairy Sci. 97:4842-4851. https://doi.org/10.3168/jds.2013-7242.

Kimura, K., J. P. Goff, M. E. Kehrli, J. A. Harp, and B. J. Nonnecke. 2002. Effects of mastectomy on composition of peripheral blood mononuclear cell populations in periparturient dairy cows. J. Dairy Sci. 85:1437-1444. https://doi.org/10.3168/jds.S00220302(02)74211-2.

Lacetera, N., D. Scalia, U. Bernabucci, B. Ronchi, D. Pirazzi, and A. Nardone. 2005. Lymphocyte functions in overconditioned cows around parturition. J. Dairy Sci. 88:2010-2016. https://doi. org/10.3168/jds.S0022-0302(05)72877-0.

LeBlanc, S. 2010. Monitoring metabolic health of dairy cattle in the transition period. J. Reprod. Dev. 56(Suppl):S29-S35.

LeBlanc, S. J. 2008. Postpartum uterine disease and dairy herd reproductive performance: A review. Vet. J. 176:102-114. https://doi. org/10.1016/j.tvjl.2007.12.019.

Li, X., X. Zhao, and S. Ma. 1999. Secretion of $92 \mathrm{kDa}$ gelatinase (MMP-9) by bovine neutrophils. Vet. Immunol. Immunopathol. 67:247-258. https://doi.org/10.1016/S0165-2427(98)00228-1.

Loor, J. J., H. M. Dann, N. A. J. Guretzky, R. E. Everts, R. Oliveira, C. A. Green, N. B. Litherland, S. L. Rodriguez-Zas, H. A. Lewin, and J. K. Drackley. 2006. Plane of nutrition prepartum alters hepatic gene expression and function in dairy cows as assessed by longitudinal transcript and metabolic profiling. Physiol. Genomics 27:29-41. https://doi.org/10.1152/physiolgenomics.00036.2006.

López-Bermejo, A., B. Chico-Julià, A. Castro, M. Recasens, E. Esteve, J. Biarnés, R. Casamitjana, W. Ricart, and J. M. Fernández-Real. 2007. Alpha defensins 1,2, and 3: Potential roles in dyslipidemia and vascular dysfunction in humans. Arterioscler. Thromb. Vasc. Biol. 27:1166-1171. https://doi.org/10.1161/ATVBAHA.106.138594.
Luenser, K., and A. Ludwig. 2005. Variability and evolution of bovine beta-defensin genes. Genes Immun. 6:115-122. https://doi. org/10.1038/sj.gene.6364153.

Mallard, B. A., J. C. Dekkers, M. J. Ireland, K. E. Leslie, S. Sharif, C. Lacey Vankampen, L. Wagter, and B. N. Wilkie. 1998. Alteration in immune responsiveness during the peripartum period and its ramification on dairy cow and calf health. J. Dairy Sci. 81:585595. https://doi.org/10.3168/jds.S0022-0302(98)75612-7.

Manco, M., J. M. Fernandez-Real, F. M. Vecchio, V. Vellone, J. M. Moreno, V. Tondolo, G. Bottazzo, G. Nanni, and G. Mingrone. 2010. The decrease of serum levels of human neutrophil alphadefensins parallels with the surgery-induced amelioration of NASH in obesity. Obes. Surg. 20:1682-1689. https://doi.org/10.1007/ s11695-010-0129-8

Manna, P., and S. K. Jain. 2015. Obesity, oxidative stress, adipose tissue dysfunction, and the associated health risks: Causes and therapeutic strategies. Metab. Syndr. Relat. Disord. 13:423-444. https://doi.org/10.1089/met.2015.0095.

Matrisian, L. M. 1990. Metalloproteinases and their inhibitors in matrix remodeling. Trends Genet. 6:121-125.

McMurray, R. W., R. W. Bradsher, R. W. Steele, and N. S. Pilkington. 1990. Effect of prolonged modified fasting in obese persons on in vitro markers of immunity: Lymphocyte function and serum effects on normal neutrophils. Am. J. Med. Sci. 299:379-385.

Ministry of Primary Industries. 1999. New Zealand Animal Welfare Act. Part 6. Use of animals in research, testing, and teaching. Accessed Jan. 24, 2015. http://www.legislation.govt.nz/act/ public/1999/0142/latest/DLM49664.html.

Moyes, K. M., J. K. Drackley, D. E. Morin, and J. J. Loor. 2010. Greater expression of TLR2, TLR4, and IL6 due to negative energy balance is associated with lower expression of HLA-DRA and HLA-A in bovine blood neutrophils after intramammary mastitis challenge with Streptococcus uberis. Funct. Integr. Genomics 10:53-61.

Moyes, K. M., D. E. Graugnard, M. J. Khan, M. Mukesh, and J. J. Loor. 2014. Postpartal immunometabolic gene network expression and function in blood neutrophils are altered in response to prepartal energy intake and postpartal intramammary inflammatory challenge. J. Dairy Sci. 97:2165-2177. https://doi.org/10.3168/ jds.2013-7433.

Nagahata, H., S. Makino, S. Takeda, H. Takahashi, and H. Noda. 1988. Assessment of neutrophil function in the dairy cow during the perinatal period. Zentralbl. Veterinarmed. B 35:747-751.

Osorio, J. S., E. Trevisi, M. A. Ballou, G. Bertoni, J. K. Drackley, and J. J. Loor. 2013. Effect of the level of maternal energy intake prepartum on immunometabolic markers, polymorphonuclear leukocyte function, and neutrophil gene network expression in neonatal Holstein heifer calves. J. Dairy Sci. 96:3573-3587.

Roche, J. R. 2007. Milk production responses to pre- and postcalving dry matter intake in grazing dairy cows. Livest. Sci. 110:12-24. https://doi.org/10.1016/j.livsci.2006.08.016.

Roche, J. R., P. G. Dillon, C. R. Stockdale, L. H. Baumgard, and M. J. VanBaale. 2004. Relationships among international body condition scoring systems. J. Dairy Sci. 87:3076-3079. https://doi. org/10.3168/jds.S0022-0302(04)73441-4.

Roche, J. R., N. C. Friggens, J. K. Kay, M. W. Fisher, K. J. Stafford, and D. P. Berry. 2009. Invited review: Body condition score and its association with dairy cow productivity, health, and welfare. J. Dairy Sci. 92:5769-5801.

Roche, J. R., E. S. Kolver, and J. K. Kay. 2005. Influence of precalving feed allowance on periparturient metabolic and hormonal responses and milk production in grazing dairy cows. J. Dairy Sci. 88:677-689. https://doi.org/10.3168/jds.S0022-0302(05)72732-6.

Roche, J. R., K. A. Macdonald, K. E. Schütz, L. R. Matthews, G. A. Verkerk, S. Meier, J. J. Loor, A. R. Rogers, J. McGowan, S. R. Morgan, S. Taukiri, and J. R. Webster. 2013. Calving body condition score affects indicators of health in grazing dairy cows. J. Dairy Sci. 96:5811-5825. https://doi.org/10.3168/jds.2013-6600.

Roche, J. R., S. Meier, A. Heiser, M. D. Mitchell, C. G. Walker, M. A. Crookenden, M. V. V. Riboni, J. J. Loor, and J. K. Kay. 2015. Effects of precalving body condition score and prepartum feed- 
ing level on production, reproduction, and health parameters in pasture-based transition dairy cows. J. Dairy Sci. 98:7164-7182. https://doi.org/10.3168/jds.2014-9269.

Scalia, D., N. Lacetera, U. Bernabucci, K. Demeyere, L. Duchateau, and C. Burvenich. 2006. In vitro effects of nonesterified fatty acids on bovine neutrophils oxidative burst and viability. J. Dairy Sci. 89:147-154. https://doi.org/10.3168/jds.S0022-0302(06)72078-1.

Selsted, M. E., Y. Q. Tang, W. L. Morris, P. A. McGuire, M. J. Novotny, W. Smith, A. H. Henschen, and J. S. Cullor. 1996. Purification, primary structures, and antibacterial activities of beta-defensins, a new family of antimicrobial peptides from bovine neutrophils. J. Biol. Chem. 271:16430.

Sordillo, L. M., and S. L. Aitken. 2009. Impact of oxidative stress on the health and immune function of dairy cattle. Vet. Immunol. Immunopathol. 128:104-109. https://doi.org/10.1016/j. vetimm.2008.10.305.

Sordillo, L. M., and V. Mavangira. 2014. The nexus between nutrient metabolism, oxidative stress and inflammation in transition cows. Anim. Prod. Sci. 54:1204-1214.

Stark, M. A., Y. Huo, T. L. Burcin, M. A. Morris, T. S. Olson, and K. Ley. 2005. Phagocytosis of apoptotic neutrophils regulates granulopoiesis via IL-23 and IL-17. Immunity 22:285-294. https://doi. org/10.1016/j.immuni.2005.01.011.
Stockdale, C. R. 2001. Body condition at calving and the performance of dairy cows in early lactation under Australian conditions: A review. Aust. J. Exp. Agric. 41:823-839.

Treacher, R. J., I. M. Reid, and C. J. Roberts. 1986. Effect of body condition at calving on the health and performance of dairy cows. Anim. Prod. 43:1-6. https://doi.org/10.1017/S0003356100018286.

Vailati-Riboni, M., M. Kanwal, O. Bulgari, S. Meier, N. V. Priest, C R. Burke, J. K. Kay, S. McDougall, M. D. Mitchell, C. G. Walker, M. Crookenden, A. Heiser, J. R. Roche, and J. J. Loor. 2016. Body condition score and plane of nutrition prepartum affect adipose tissue transcriptome regulators of metabolism and inflammation in grazing dairy cows during the transition period. J. Dairy Sci. 99:758-770. https://doi.org/10.3168/jds.2015-10046.

Vandesompele, J., K. De Preter, F. Pattyn, B. Poppe, N. Van Roy, A. De Paepe, and F. Speleman. 2002. Accurate normalization of real-time quantitative RT-PCR data by geometric averaging of multiple internal control genes. Genome Biol. 3:RESEARCH0034.

Zhou, Z., D. P. Bu, M. V. Riboni, M. J. Khan, D. E. Graugnard, J. Luo, F. C. Cardoso, and J. J. Loor. 2015. Prepartal dietary energy level affects peripartal bovine blood neutrophil metabolic, antioxidant, and inflammatory gene expression. J. Dairy Sci. 98:54925505. https://doi.org/10.3168/jds.2014-8811. 